\title{
REMOTE SENSING OF TROPOSPHERIC POLLUTION FROM SPACE
}

by Jack Fishman, Kevin W. Bowman, John P. Burrows, Andreas Richter, Kelly V. Chance,

David P. Edwards, Randall V. Martin, Gary A. Morris, R. Bradley Pierce, Jerald R. Ziemke, Jassim A. Al-SaAdi. John K. Creilson, TOdd K. SChaAck, And Anne M. Thompson.

Geostationary satellite observations of chemically reactive trace gases will provide unique insight into the evolution and extent of air pollution with the temporal resolution necessary to address air quality on a daily basis.

T he ability to measure air pollution and other chemically reactive trace gases in the lower atmosphere from satellites has a heritage dating back nearly three decades when the first measurements of carbon monoxide (CO) were made from the space shuttle Challenger in November 1981 (Reichle et al. 1986). Since then, numerous satellite-based instruments have provided important measurements from Earth-observing platforms in low-Earth orbit (LEO), giving nearly global coverage of several key trace gases (National Research Council 2008). The National Aeronautics and Space Administration (NASA) Aura satellite, originally proposed as a component of the Earth Observing System (EOS) concept in the 1980 s, is the most recently launched (2004)
U.S. satellite dedicated to measuring trace gases; with other satellites currently sending back atmospheric composition measurements, this decade is unique with respect to the amount of information coming from space to provide new insight into processes that control the observed distributions.

Despite significant scientific achievements derived from Aura and other satellites, there are no plans to launch an Aura follow-on. Furthermore the kinds of data that are likely to come from the next generation of satellites will probably be different from what has been seen in the past, according to the National Research Council (NRC), which recently issued a comprehensive report (see "The NRC Report" sidebar) defining the national priorities for space-




based measurements in the forthcoming decade (National Research Council 2007). For atmospheric composition, the report recommended a continuation of the measurement of the trace species already being measured ["top-priority measurements include tropospheric ozone $\left(\mathrm{O}_{3}\right), \mathrm{CO}$, nitrogen dioxide $\left(\mathrm{NO}_{2}\right)$, formaldehyde ( $\mathrm{HCHO})$, sulfur dioxide $\left(\mathrm{SO}_{2}\right)$, and aerosols"]. However, the report further stated that a combination of satellites from both LEO and geostationary Earth orbit (GEO) should be launched, with the "highest priority being a GEO mission." The NRC's GEO recommendation is consistent with their paradigm that future Earth observations should have direct societal benefit, in addition to providing data primarily for scientific purposes, as has been the priority in the past.

Thus, as a survey of past, present, and future capabilities, the purpose of this paper is threefold. First, we review the progress of the measurements of trace gas distributions that provide the scientific community with the first global distributions of several key species. Second, we show an example of the current research capabilities that now assimilate composition measurements into chemical transport models to provide consistent pictures of multiple species at a specific time. And last, if the next generation of tropospheric trace gas measurements is to supply information that will be used to improve our understanding of air quality, as well as to provide the observations necessary to mitigate harm to society, then such observations must be used in conjunction with operational models. This paradigm is greatly different from the rationale that lay behind the launch of the past and present fleet of satellites. Therefore, in the last part of this paper, we present a preview of research operational air quality forecasting products (Dabberdt et al. 2003; McHenry and Dabberdt 2005) and provide a snapshot of the kind of measurements recommended in the National Research Council (2007) report.

AfFiliations: Fishman, Al-SAadi, and Creilson-NASA Langley Research Center, Hampton, Virginia; Bowman-Jet Propulsion Laboratory, Pasadena, California; BURROWS AND RICHTER-University of Bremen, Bremen, Germany; CHANCE-Harvard-Smithsonian Center for Astrophysics, Cambridge, Massachusetts; EdwARDSNational Center for Atmospheric Research, Boulder, Colorado; MARTIN-Dalhousie University, Halifax, Nova Scotia, Canada, and Smithsonian Center for Astrophysics, Harvard University, Cambridge, Massachusetts; MORRIS - Valparaiso University, Valparaiso, Indiana; PIERCE-NOAA/NESDIS/STAR, Madison, Wisconsin; ZIEMKE-NASA Goddard Space Flight Center, Greenbelt, Maryland; SCHAACK-University of Wisconsin-Madison, Madison, Wisconsin;
TROPOSPHERIC TRACE GAS MEASUREMENTS FROM SPACE. At lower altitudes, many of the standard techniques that can be used to derive information about the stratosphere by viewing the Earth's limb (e.g., see Burrows 1999; Kaye and Fishman 2003) cannot be used, and, therefore, nadir viewing is required. Because several tropospheric trace species can also be present in significant quantities in the stratosphere, altitude discrimination between what is present in the troposphere and what is present in the stratospheric overburden becomes a challenge to instrument retrieval development. Key measurable trace gases that are prevalent in both the troposphere and stratosphere include ozone, as well as its most important precursor for in situ tropospheric production, $\mathrm{NO}_{2}$. A few important trace gases present predominantly in the lower atmosphere with enough of a spectral signature to be observed from a space platform include $\mathrm{CO}, \mathrm{HCHO}, \mathrm{SO}_{2}$, and the long-lived greenhouse gases carbon dioxide $\left(\mathrm{CO}_{2}\right)$ and methane $\left(\mathrm{CH}_{4}\right)$.

Tropospheric trace gas measurements from space were originally to be part of NASA's Nimbus-7 satellite, launched in 1978. Proposed to be on board was the Measurement of Air Pollution from Satellites (MAPS) instrument, a gas-filter correlation radiometer (GFCR) designed to measure carbon monoxide, which is a species of tropospheric origin and a key player in the reactions of other trace gases through its reaction with the hydroxyl radical (Crutzen and Fishman 1977; Thompson 1992). In the early 1970s, the global sources of CO were in dispute (McConnell et al. 1971; Seiler 1974), with some studies suggesting that natural sources (e.g., oxidation of methane and nonmethane hydrocarbons) were an order of magnitude larger than anthropogenic emissions (National Academy of Science 1977). A global survey of CO from space would determine the relative strengths of these sources. The then-fledgling Environmental Protection Agency would benefit by knowing whether

THOMPSON-The Pennsylvania State University, University Park, Pennsylvania CORRESPONDING AUTHOR: Jack Fishman, Mail Stop 40IA, NASA Langley Research Center, Hampton, VA 2368I-2199 E-mail: jack.fishman@nasa.gov

The abstract for this article can be found in this issue, following the table of contents.

DOI: $10.1175 / 2008$ BAMS2526.1

In final form 8 January 2008

(C)2008 American Meteorological Society 
the human component of $\mathrm{CO}$ was large enough that regulations on $\mathrm{CO}$ would improve air quality.

When NASA's Nimbus-7 was actually launched in 1978, the MAPS instrument had been removed from the payload. MAPS was modified to fly on the space shuttle and flew four times between 1981 and 1994 (Reichle et al. 1999), providing "snapshots" of CO distributions. These initial glimpses confirmed that $\mathrm{CO}$ was highest where human sources from industry and tropical fires dominated. Subsequent to MAPS, the Interferometric Monitor of Greenhouse Gases (IMG) obtained CO measurements for several months aboard the Japanese Advanced Earth Observing System (ADEOS) satellite in 1996-97 (Hadji-Lazaro et al. 1999; Barret et al. 2005) using a Fourier transform spectrometer. The IMG observations provided confirmation of the findings from
MAPS, but operated for less than a year because of the failure of the ADEOS platform in June 1997.

The Measurement of Pollution in the Troposphere (MOPITT) instrument, a GFCR, has been measuring CO from NASA's Terra satellite since 1999. MOPITT's relatively long-term record has been used to determine the impact of localized emissions on global air quality. Among the unanticipated findings was that wildfires in North America and Siberia were surprisingly strong sources of CO (Lamarque et al. 2003; Edwards et al. 2004), which caused ecosystem changes and alterations to the carbon balance over Earth's vegetated areas through removal of aboveground biomass, transport of $\mathrm{CO}$ and $\mathrm{CO}_{2}$ into the atmosphere, and alteration of the carbon uptake by ecosystems. The 2004 Alaskan wildfire season was the region's worst on record because of unusually

\section{THE NRC REPORT}

In 2004, NASA, NOAA, and the U.S. Geological Society (USGS) requested that the NRC form a panel to identify and prioritize the next set of observational platforms that should be launched and operated over the next decade. In addition to providing information solely for the purpose of addressing scientific questions, the NRC took the approach that increasing the societal benefits of Earth science research should likewise be high on the priority list of federal science agencies and policy makers, who have long believed that the role of scientific research is not only to expand our knowledge, but also to improve the lives of Americans.

For example, in the U.S. today, an estimated 1.8-3.I yr of life are lost to people living in the most polluted cities due to chronic exposure to particulates (Pope 2000), and more than 4,000 premature deaths per year occur because of the elevated ozone concentrations now commonly observed in the United States (Bell et al. 2004). Elevated surface ozone concentrations also have deleterious effects on crop production (Mauzerall and Wang 200I; Morgan et al. 2003) costing U.S. agriculture more than a billion dollars annually.

The NRC emphasized that if Earth scientists are to foster applications and extend the societal benefits of their work, they must also understand the research-to-applications chain, which includes transforming satellite measurements into useful information and distributing that information in a form that is understandable and meets the needs of both public- and privatesector managers, decision makers, and policy makers.

Specifically, with respect to future atmospheric chemistry missions, the National Research Council (2007) recommended that a mission dedicated to the measurement of tropospheric trace gases from a geostationary spacecraft should be launched in the 2013-16 time frame [Geostationary Coastal and Air Pollution Events (GEO-CAPE) mission], and that such a mission would fit into its vision of providing societal benefit. The NRC also called for another satellite similar to Aura to be launched again in the 2020 time frame [Global Atmospheric Composition Mission (GACM)].

The use of Earth science data for applications will first require gaining an understanding of how researchlevel data can be used in a successful operational environment (National Research Council 2007). Extracting societal benefit from spaceborne measurements necessitates, as an equally important second step, the development of a strong link between the measurements and decision makers who will use such measurements. This linkage must be created and sustained throughout the life cycle of the space mission. In order to implement future missions, scientists who are engaged in research intended to have both scientific and societal contributions must operate differently than they did in the days when the advancement of science was either the primary or only goal of research. Applications development places new responsibilities on agencies to balance applications demands with scientific priorities, and the character of missions may change in significant ways if societal needs are given equal priority with scientific needs. This potential societal benefit was interwoven into the foundation for the NRC requirement of making atmospheric composition measurements from a geostationary platform its highest priority. As this new paradigm evolves, the numbers of published papers, scientific citation indices, or even professional acclamation from scientific peers will not be enough to evaluate the success of the missions that have been recommended. The degree to which human welfare has been improved and the effectiveness of protecting property and saving lives will additionally become important criteria for a successful Earth science and observations program. 
warm and dry weather; in central Alaska and Canada's Yukon Territory, more than 11 million acres burned. The location of high CO values measured by MOPITT (Fig. 1) coincided with the location of fires and aerosol plumes seen by the Moderate Resolution Imaging Spectroradiometer (MODIS) that was also on Terra. Model analysis using these observations showed that the fires were responsible for $\sim 30 \mathrm{Tg}$ of CO during summer 2004, which is roughly equivalent to the total U.S. anthropogenic $\mathrm{CO}$ emissions during that time. Ground-level ozone increased by about $25 \%$ in the northern United States and impacted ozone amounts in the free troposphere as far away as Houston, Texas (Morris et al. 2006), and Europe (Pfister et al. 2005). From its first observations of immense $\mathrm{CO}$ plumes from forest and grassland fires in Africa and South America that traveled as far as Australia, MOPITT has provided the community with a tool for studying pollution sources, chemistry, and transport in detail.

The Atmospheric Infrared Sounder (AIRS) instrument on board the Aqua satellite (launched in 2002) is also capable of providing information about $\mathrm{CO}$ (McMillan et al. 2005). Some preliminary products are currently being developed to use this information in near-real time to investigate sources of $\mathrm{CO}$ and transport patterns. Comparisons of the CO data from AIRS with concurrent MOPITT observations (Warner et al. 2007) show some promise for these data, which have the advantage of providing near-global coverage on a daily basis. Most recently, the Infrared Atmospheric Sounding Interferometer (IASI) on the European Meteorological Operation MetOp-A satellite has also been providing $\mathrm{CO}$ measurements as an operational product since 2007 (information available online at http://smsc.cnes.fr/IASI/GP_satellite.htm; see also Turquety et al. 2004).


FIG. I. MOPITT 700-hPa CO mixing ratio for 15-23 Jul 2004, during the INTEX-NA field campaign. The intense wildfires in Alaska produced plumes of pollution that can be traced across North America and the Atlantic Ocean.
TROPOSPHERIC TRACE GAS INFORMATION FROM SATELLITE MEASUREMENTS DESIGNED TO STUDY THE STRATOSPHERE. The Total Ozone Mapping Spectrometer (TOMS) instrument aboard Nimbus-7 was designed to produce global daily maps of total ozone so that stratospheric ozone depletion (a hypothesis in 1978) could be observed and quantified, and the processes leading to it understood (Molina and Rowland 1974). Working on the principle of measuring backscattered ultraviolet (BUV) radiation, TOMS primarily provided information about the distribution of ozone in the stratosphere where $\sim 90 \%$ of the ozone in the atmosphere $(\sim 15-55 \mathrm{~km})$ is found. The remaining $\sim 10 \%$ is located in the troposphere below the tropopause, which is generally located at $10-18-\mathrm{km}$ altitude and varies as a function of both latitude and time of year. In the tropics, the tropopause is located higher in the atmosphere $(16-18 \mathrm{~km})$ than at middle latitudes, where its height can be as low as $6-8 \mathrm{~km}$ (winter), or as high as $15-16$ $\mathrm{km}$ (summer).

The amount of ozone in a column of air is expressed in Dobson units (DU), where 1 DU has a value of $2.69 \times 10^{16}$ molecules of ozone per square centimeter. A representative amount of total column ozone is $300 \mathrm{DU}$, of which $\sim 30 \mathrm{DU}$ is in the troposphere. At middle latitudes, the synoptic distribution of total ozone is primarily determined by the largerscale distribution of ozone within the stratosphere; in turn, these patterns generally follow the upper-level airflow on a daily basis, with the polar jet often being the demarcation between higher-stratospheric ozone poleward and lesser amounts at lower latitudes. At low latitudes, therefore, large-scale synoptic patterns of total ozone are often not definitive because of the much weaker pressure gradients generally present there. In Fig. 2, the monthly distribution of total ozone is depicted. Note that the figure uses a color scale, where the total ozone features at middle and high latitudes are off the scale for better visualization of low-latitude variability (Fishman et al. 1990). The enhancements in total ozone found at low latitudes over the South Atlantic and adjacent continents are generally observed during austral spring (September- 


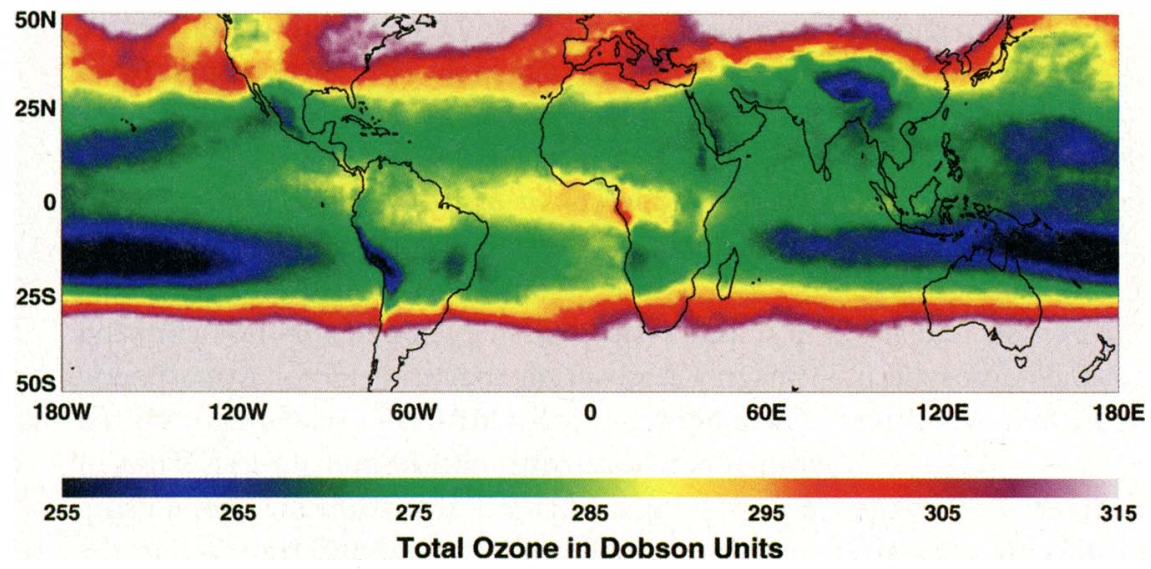

Fıg. 2. Total ozone distribution for Sep 1987 as determined from the TOMS satellite (from Fishman et al. 1990).

November). Furthermore, a significant positive correlation was found with $\mathrm{CO}$ measurements from the first MAPS shuttle flight in November 1981 (Fishman et al. 1986).

The data depicted in Fig. 2, however, reflect total ozone measurements, of which only a relatively small percentage is found in the troposphere. At higher latitudes, meteorological activity is generally more vigorous, and persistent patterns over periods of a week or two are rare. Therefore, identification of enhanced tropospheric ozone is difficult, and quasipersistent plumes from Europe and northern Asia would be lost beneath the stratospheric variability. Persistent ozone sources in the tropics offered the first indications that total ozone column satellite information could be used to identify ozone pollution sources.

Extracting tropospheric ozone from total ozone column measurements. The first step in retrieving the amount and distribution of many important tropospheric trace gases through space-based observations such as TOMS is to find a method for separating the tropospheric and stratospheric components. Before that methodology was developed, however, an important ozone analysis was provided in Fishman and Larsen (1987) in which Stratospheric Aerosol and Gas Experiment (SAGE) ozone profiles were used to calculate the stratospheric column ozone (SCO), which showed that stratospheric ozone at low latitudes exhibited little longitudinal variability. TOMS measurements, on the other hand, between $15^{\circ} \mathrm{N}$ and $15^{\circ} \mathrm{S}$, showed that the distribution of total ozone was quite different from the SCO distribution, and was generally highest over the south tropical Atlantic Ocean.

During the 1990s, a number of research groups focused on extracting information about the tropo- sphere from satellite measurements by assuming that ozone variability in the stratosphere is defined on relatively large spatial scales, compared with the troposphere, so that information could be obtained about the troposphere if this larger-scale stratospheric component could be isolated. Once the stratospheric ozone distribution was determined, the "residual" information [tropospheric ozone residual (TOR)] could be used to infer information about the troposphere (see Fig. 3).

Using standard tropopause height information from the National Centers for Environmental Prediction (NCEP) in conjunction with collocated TOMS total ozone and SAGE profiles, Fishman et al. (1990) produced the first climatological depiction of tropospheric ozone on a domain that included both the tropics and middle latitudes (from $\sim 50^{\circ} \mathrm{N}$ to $\sim 50^{\circ} \mathrm{S}$ ). The seasonal climatology of the TOR showed elevated amounts of tropospheric ozone at northern temperate latitudes during the summer, and in the tropics and subtropics in the Southern Hemisphere during austral spring, with the latter being a consequence of widespread biomass burning during that time of the year. This surprising finding in the South Atlantic became the focus of a major field campaign in 1992: Transport and Atmospheric Chemistry near the Equator-Atlantic (Fishman et al. 1996).

Subsequent to the TOMS-SAGE-derived TOR being published in 1990, a number of research groups employed other methodologies to independently



FIG. 3. Schematic of the TOR technique. 
calculate SCO values and to derive a quasi-global TOR distribution (e.g., Thompson and Hudson 1999). SCO distributions were derived from the Microwave Limb Scanner (MLS) and the Halogen Occultation Experiment (HALOE) profiles from the Upper Atmosphere Research Satellite (UARS) launched in 1991 (Ziemke et al. 1998) and the solar backscattered ultraviolet (SBUV) profiles from Nimbus-7 and several subsequent National Oceanic and Atmospheric Administration (NOAA) operational satellites (Fishman et al. 2003; Fig. 4).

Other techniques used characteristics of the TOMS measurements alone to develop a means of constructing an independent SCO value using information about how the TOMS made its total column measurement. Two of these techniques compare the amount of total ozone at locations that are affected by the presence of clouds with total ozone amounts in nearby cloud-free regions. The difference in the column amounts is then defined as the tropospheric column ozone (TCO). Furthermore, by having independent information about the height of the clouds, upper-tropospheric ozone profiles can then be calculated (Ziemke et al. 1998, 2001). In a somewhat similar technique, TCO has been derived using total column measurements above and adjacent

\section{December-February}
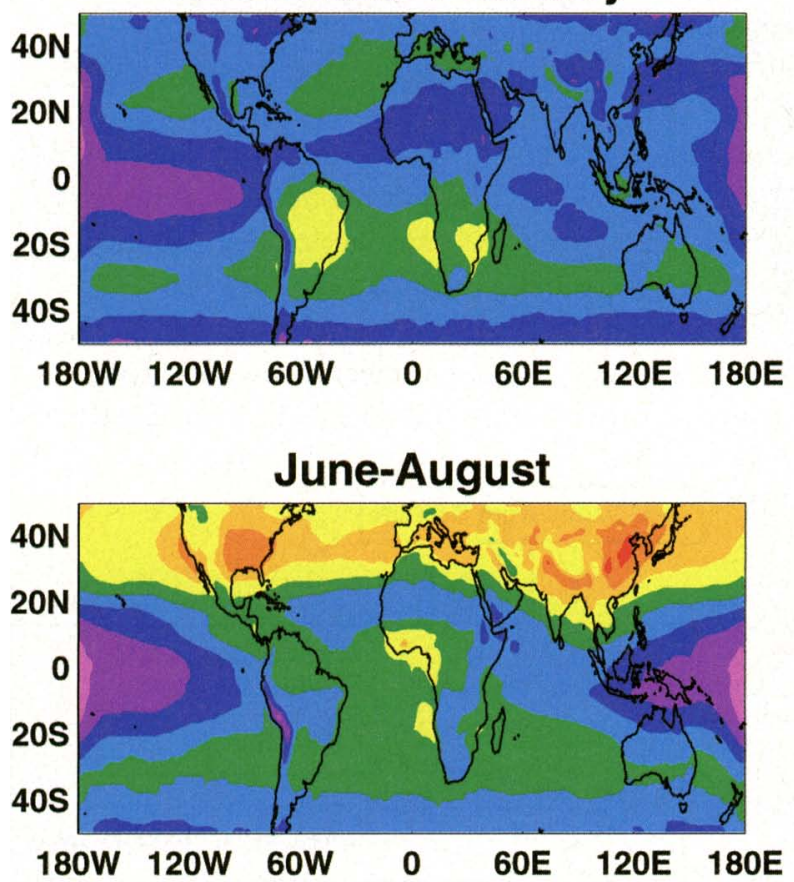

to mountains of known heights, with the difference identified as the TCO in the layer up to mountaintop height (Newchurch et al. 2001).

Direct measurement of tropospheric ozone. Direct determination of ozone profiles, including tropospheric ozone, from nadir measurements in the UV and visible was developed for the Scanning Imaging Absorption Spectrometer for Atmospheric Chartography (SCIAMACHY) instrument on the European Environmental Satellite (ENVISAT) by applying a retrieval algorithm for ozone using information from differential penetration into the atmosphere. An altitude dependence was then determined by fitting the absorption to the temperaturedependent ozone Huggins bands (Chance et al. 1991, 1997; Bhartia et al. 1996). The method was originally applied to the Global Ozone Monitoring Experiment (GOME) spectral measurements (Munro et al. 1998; Hoogen et al. 1999) and has now been used to determine a multiyear climatology of tropospheric ozone (Liu et al. 2005, 2006). SAGE also obtained direct measurements of ozone in the upper troposphere at low latitudes by using an occultation technique when cumulus clouds are not present (Wang et al. 2006). Each of the direct measurement techniques
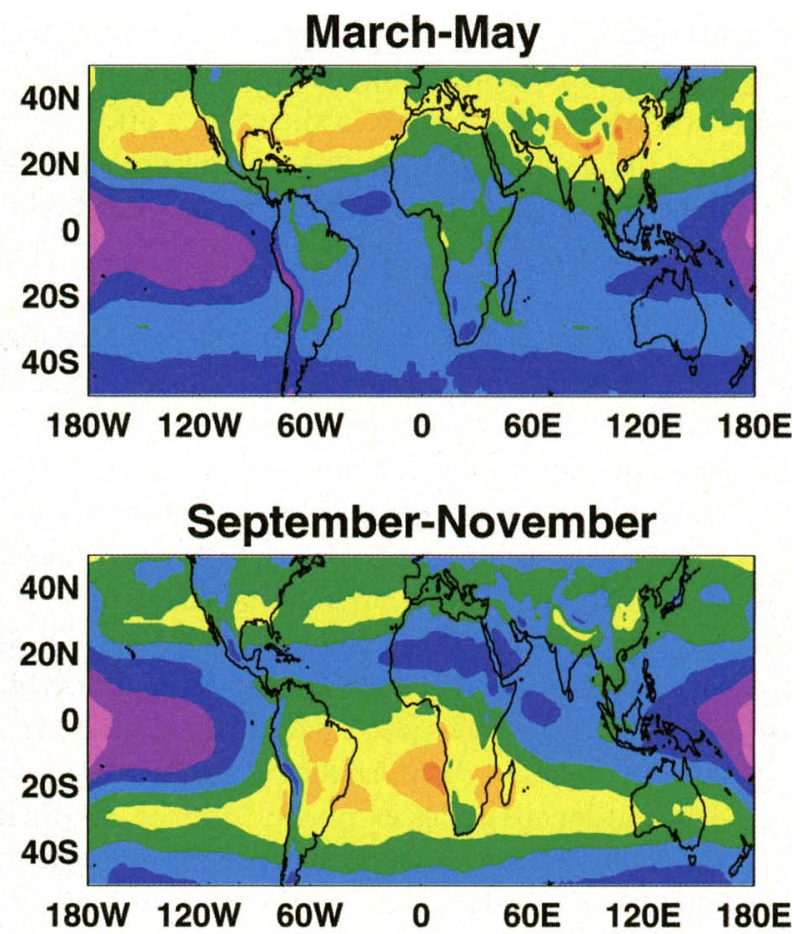

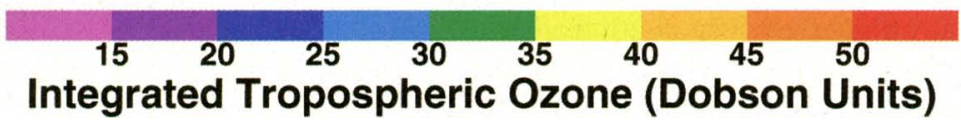

FIG. 4. Climatological depiction of TOR using TOMS and SBUV measurements (Fishman et al. 2003). 
produces tropospheric ozone distributions consistent with the features originally found using the TOR methodology.

TROPOSPHERIC NO $\mathbf{N}_{2}$. Although significant quantities of $\mathrm{NO}_{2}$ are found in both the stratosphere and troposphere, the amount can vary by more than two orders of magnitude, with nearly all of this variability in the troposphere. The amount in the stratosphere is first determined empirically using the knowledge that stratospheric $\mathrm{NO}_{2}$ is most dependent on the length of day (i.e., the integrated photolysis of the reactive nitrogen reservoirs), and thus has a strong latitudinal dependence. Defining a value of $\mathrm{NO}_{2}$ found over a region far from pollution sources (generally over the Atlantic or Pacific) as the stratospheric component of the total column at that latitude is the first step for determining how much $\mathrm{NO}_{2}$ is in the troposphere. This quantity is then subtracted from the observed $\mathrm{NO}_{2}$ total column for the rest of the day at the same latitude to derive how much of that $\mathrm{NO}_{2}$ is in the troposphere (Richter and Burrows 2002). Alternatively, the stratospheric $\mathrm{NO}_{2}$ contribution can also be estimated using chemical transport models (CTMs) or assimilated $\mathrm{NO}_{2}$ fields. Tropospheric $\mathrm{NO}_{2}$ columns have been retrieved independently from GOME, SCIAMACHY, and the Ozone Monitoring Instrument (OMI) by several groups (Martin et al. 2002; Richter and Burrows 2002; Beirle et al. 2003; Boersma et al. 2004; Bucsela et al. 2006). Figure 5 shows tropospheric $\mathrm{NO}_{2}$ columns retrieved from SCIAMACHY (Martin et al. 2006). Pronounced enhancements are evident over major urban and industrial regions. The high degree of spatial heterogeneity provides empirical evidence that most of the tropospheric $\mathrm{NO}_{2}$ column is concentrated in the lower troposphere and close to local emissions. As a result, tropospheric $\mathrm{NO}_{2}$ columns retrieved from satellite observations show considerable prospects for inferring surface nitrogen oxides $\left(\mathrm{NO}_{\mathrm{x}}\right)$ emissions through inversion of the $\mathrm{NO}_{2}$ observations (Leue et al. 2001; Martin et al. 2003; Jaeglé et al. 2005).

FORMALDEHYDE. Formaldehyde was hypothesized to exist in ubiquitous quantities in Levy's (1971) classic paper on tropospheric photochemistry as an intermediate product of methane oxidation through reactions with the hydroxyl radical $(\mathrm{OH})$. Background $\mathrm{HCHO}$ concentrations coming directly from $\mathrm{CH}_{4}$ oxidation are too small to be observed from present-day satellites, but the oxidation of other volatile organic compounds (VOCs) that react quickly with $\mathrm{OH}$ also produces large amounts of HCHO. Thus, $\mathrm{HCHO}$ serves as a major proxy for these species when they are present in large quantities. Formaldehyde was first measured from GOME spectra during the intense biomass burning over Asia in 1997 (Thomas et al. 1998). Development of more sensitive measurement capabilities has led to a global HCHO climatology that is used to determine the distribution of VOC emissions (Chance et al. 2000; Abbot et al. 2003; Shim et al. 2005; Fu et al. 2007). Figure 6 depicts the average HCHO distribution during August 2005 from OMI. The major source region over the United States is in the southeastern states where densely populated deciduous forests permeate the landscape. Although anthropogenic VOC emissions are also important for the generation of photochemical pollution, the

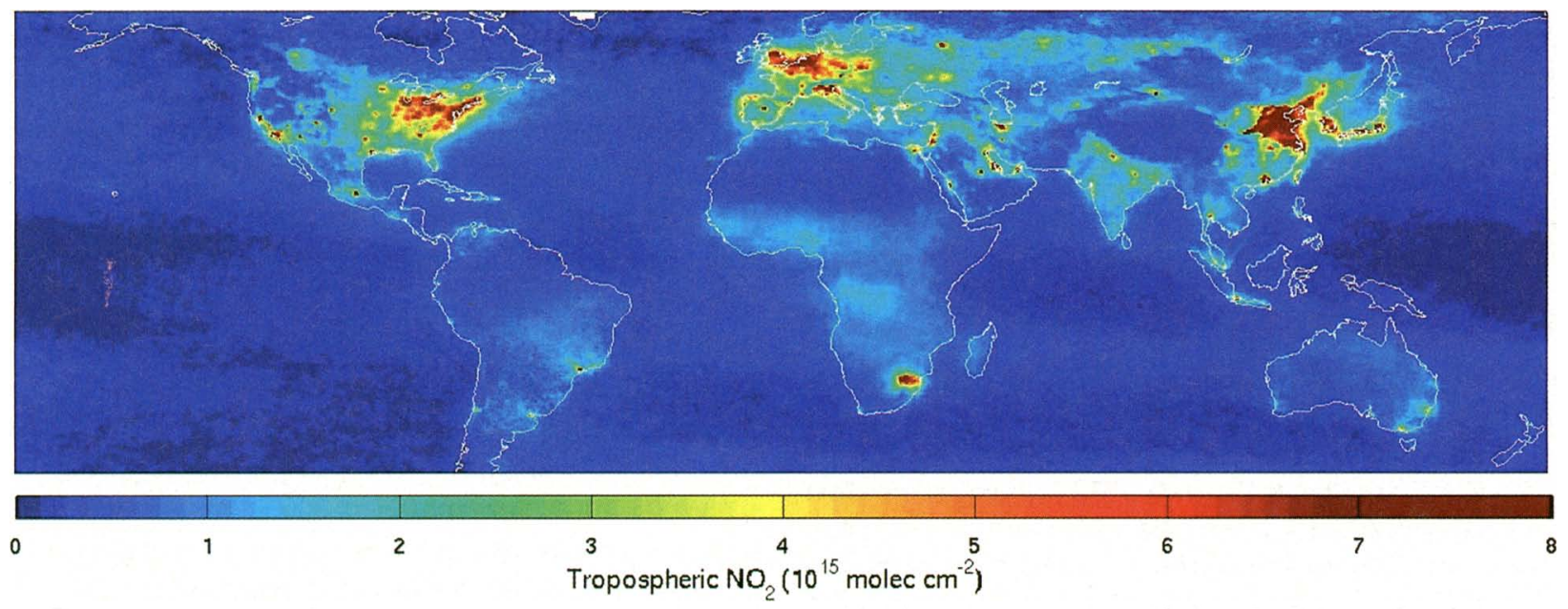

Fig. 5. Tropospheric $\mathrm{NO}_{2}$ columns retrieved by Martin et al. (2006) from the SCIAMACHY satellite instrument for Jan 2003-Dec 2005 inclusive. 



FIG. 6. HCHO distribution during Aug 2005.



$\mathrm{HCHO}$ distribution illustrates the dominance of the natural sources in this region. Recently, the glyoxal radical, $\mathrm{CHOCHO}$, has been measured from space, using OMI and SCIAMACHY spectra (Kurosu et al. 2005; Wittrock et al. 2006); glyoxal is another proxy for VOC sources with shorter lifetimes, and likely serves as a better indicator of urban sources (Volkamer et al. 2005).

PROVIDING GLOBAL INSIGHT INTO TRENDS AND INTERANNUAL VARIABILITY. As tropospheric trace gas data records extend to a decade or longer, important trend information about some emissions in specific regions of the world is now becoming available. For example, $\mathrm{NO}_{2}$ measurements from the GOME and SCIAMACHY instruments (Fig. 7) show an increase in tropospheric $\mathrm{NO}_{2}$ columns over industrial China during the last decade, confirming substantially larger regional emissions than a decade earlier (Richter et al. 2005). This same dataset also shows that emissions have decreased over much of Europe and that trends in the United States

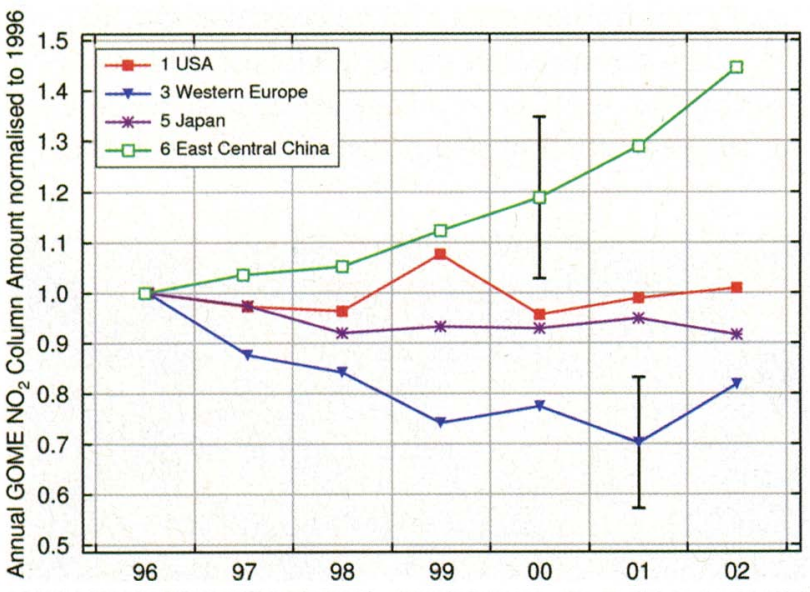

FIG. 7. (top) The monthly averages of tropospheric vertical columns of $\mathrm{NO}_{2}$ over east-central China defined for the area bounded by $30^{\circ}-40^{\circ} \mathrm{N}$ and by $110^{\circ}-123^{\circ} \mathrm{E}$ are shown. Both GOME (blue open circles) and SCIAMACHY (red filled circles) are shown. (bottom) Annual trend information for the above region (China), a region over Europe, one over the United States, and one over Japan (after Richter et al. 2005) are shown. and Japan were near zero, if not slightly downward, over this time frame. From the analysis of long-term tropospheric ozone column measurements using the multidecadal record of TOMS, several studies have suggested that the tropospheric ozone column has increased since the early 1980s (Ziemke et al. 2005; Jiang and Yung 1996).

The MOPITT dataset now provides a global record of the recent interannual variability of tropospheric air quality. The observed variability is greater than previously believed due to large fire emissions being affected by climatic conditions that control rainfall and vegetation drying (Fig. 8). These data form the foundation of a long-term observational record that is used to investigate links among chemistry, climate, and other components of the Earth system (Edwards et al. 2003, 2004; Yurganov et al. 2005). For example, strong correlations have been observed between Southern Hemisphere CO zonal average loading, fire activity in Indonesia, and El Niño conditions (Edwards et al. 2006). 
Regional interannual variability of tropospheric ozone has been linked to El Niño-Southern Oscillation in both western Africa and northern India (Fishman et al. 2005). As seen in Fig. 9, considerably more tropospheric ozone is present in northeastern India in June during an "El Niño" year (1982) than over the same region during a "La Niña" year (1999). The primary reason for this is the delay of the onset of the summer monsoon during El Niño years, thereby providing more favorable conditions for the photochemical generation of ozone pollution throughout the entire month. Also seen in this figure is the generally higher amount of tropospheric $\mathrm{O}_{3}$ observed over eastern China in 1999 compared with that in 1982. Fishman et al. (2005) showed that there was no correlation between TOR amounts and ENSO indices over eastern China, but the difference shown in these panels is consistent with the increasing trend found downwind over the Pacific (Ziemke et al. 2005), as well as with the sizeable increase of $\mathrm{NO}_{2}$ observed by GOME and SCIAMACHY over eastern China (Richter et al. 2005).

TROPOSPHERIC MEASUREMENTS AND DATA ASSIMILATION. Launched in 2004,



Aura is an entire satellite devoted to atmospheric chemistry. The Tropospheric Emission Spectrometer (TES), a Fourier transform spectrometer whose heritage traces back to the Infrared Interferometer Spectrometer (IRIS) aboard the Nimbus-4 spacecraft (Hanel and Conrath 1969), provides simultaneous observations of $\mathrm{CO}$ and tropospheric $\mathrm{O}_{3}$ vertical profiles (Beer 2001). Simultaneous observations of

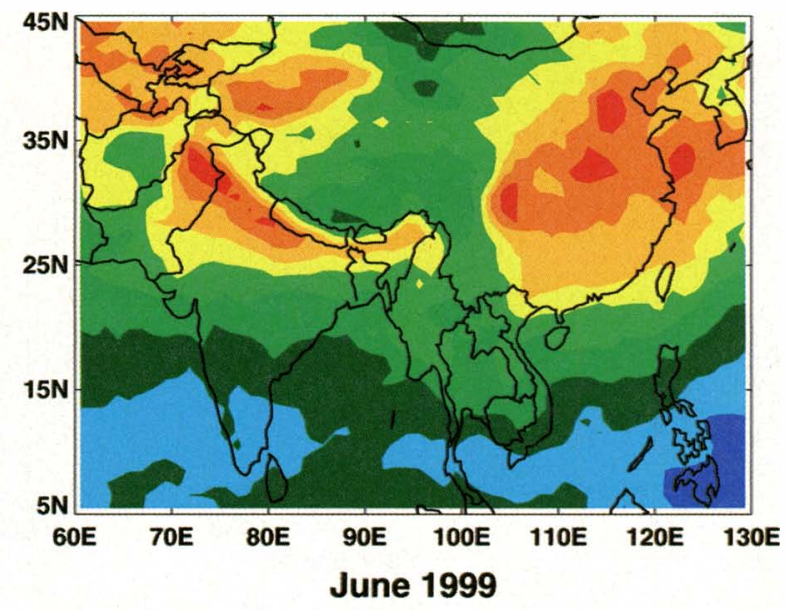

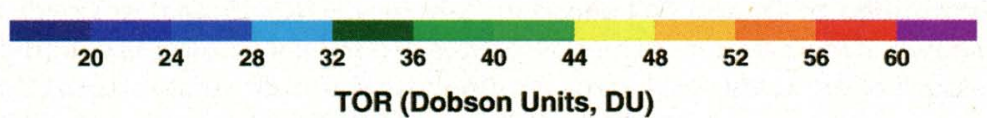

FıG. 9. Monthly distributions of TOR (DU) during Jun 1982 (EI Niño year) and Jun 1999 (La Niña year). 
these two species are particularly valuable for distinguishing between natural and anthropogenic sources of ozone (Fishman and Seiler 1983). IASI, a French instrument aboard the European MetOp-A satellite (Turquety et al. 2004), started providing concurrent $\mathrm{CO}$, tropospheric $\mathrm{O}_{3}$, and $\mathrm{CH}_{4}$ in 2007, in addition to the GOME-2 $\mathrm{NO}_{2}$ product that is also aboard MetOp-A. The spatial and vertical information from these measurements is critical for understanding the complex interplay between dynamics and chemistry


that determines the global distribution of ozone in the troposphere.

The value of concurrent measurements is further enhanced through data assimilation. For example, the tool used to derive the fields in Fig. 10 is from the NASA Langley Research Center/University of Wisconsin (LaRC/UW) Regional Air Quality Modeling System (RAQMS; Pierce et al. 2003, 2007). The assimilation of OMI data provides an overall constraint on total column ozone, while the assimilation
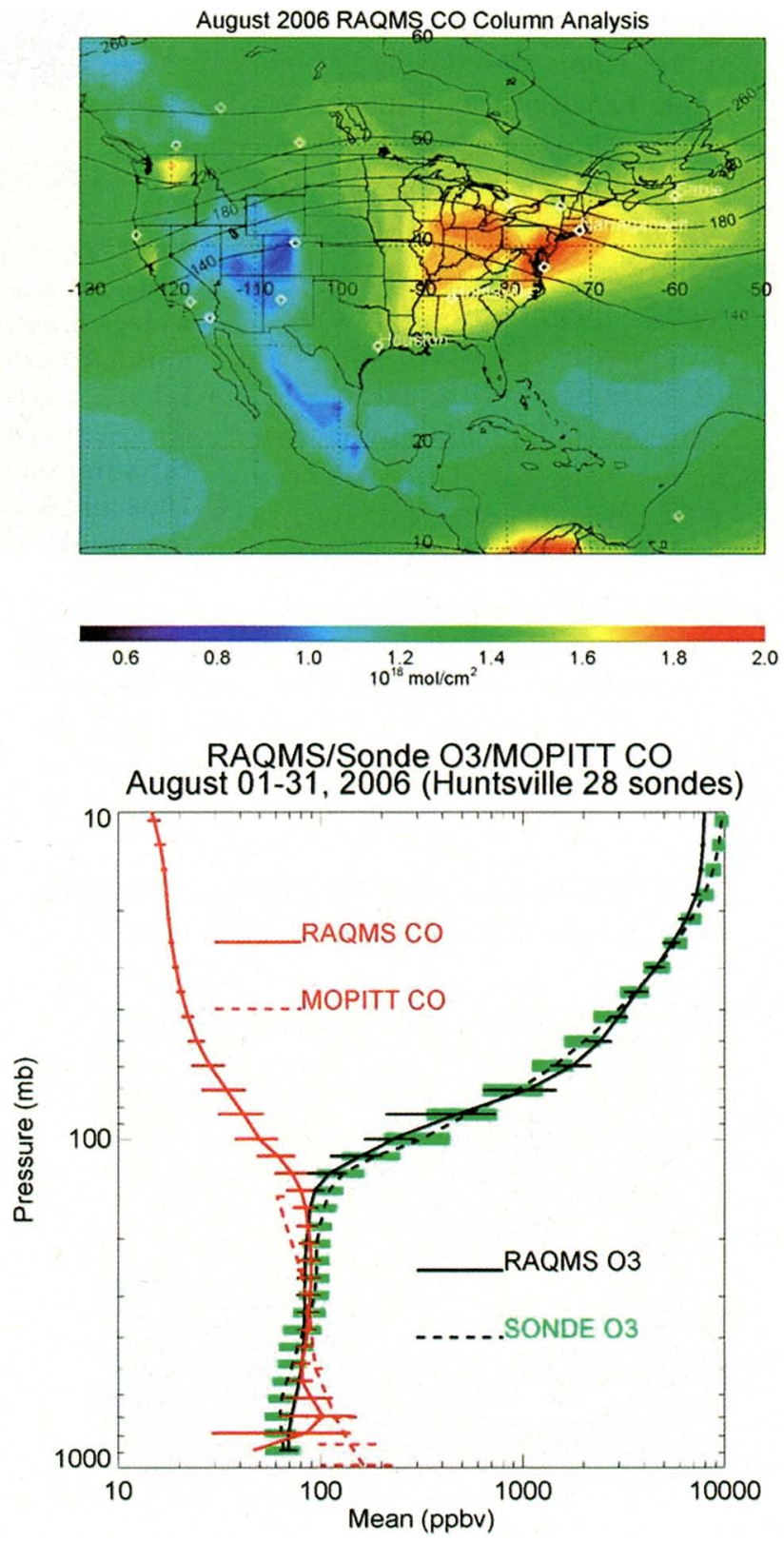

FIG. 10. (top) Mean distribution of $\mathrm{O}_{3}$ and $\mathrm{CO}$ based on 6-hourly RAQMS analyses over the continental United States during 2006 is shown. The location of the IONS sites are indicated by white diamonds with selected sites labeled. The mean pressure of the analyzed thermal tropopause is contoured. (bottom) Comparisons for Houston and Huntsville IONS sites are shown. RAQMS (solid) and MOPITT (dashed) mean CO profiles and standard deviations (red), RAQMS (solid) and IONS (dashed) mean $O_{3}$ profiles (black) and std devs (green) are shown. 
of profile retrievals constrains lower-stratospheric and tropospheric $\mathrm{O}_{3}$ and $\mathrm{CO}$ from TES. The RAQMS meteorological forecasts are initialized from NOAA's Global Forecast System (GFS) analyses at 6-h intervals, and the RAQMS OMI column assimilation likewise occurs at 6-h intervals. The RAQMS TES $\mathrm{O}_{3}$ and $\mathrm{CO}$ assimilation occurs at 1 -h intervals.

Daily ozonesonde launches were conducted throughout the continental United States during August 2006 as part of the Intercontinental Chemical Transport Experiment Ozonesonde Network Study (IONS) program (Thompson et al. 2007). The average profile distributions in Fig. 10 show the August mean
RAQMS-analyzed tropospheric $\mathrm{O}_{3}$ and total $\mathrm{CO}$ columns along with comparisons between RAQMS and IONS $\mathrm{O}_{3}$, and RAQMS and MOPITT CO for selected IONS sites. Mean MOPITT CO profiles at the IONS ozonesonde sites were obtained through composites of all daytime MOPITT observations within $1^{\circ}$ of an IONS site during August 2006.

The analyzed tropospheric ozone columns seen in Fig. 10 show a broad maximum in excess of $50 \mathrm{DU}$ over the south-central and eastern United States and the western Atlantic, and a localized ozone maximum off the California coast. The analyzed total column CO distribution shows a similar CO maximum over

\section{BASIC TROPOSPHERIC CHEMISTRY AND WHAT CAN BE OBSERVED FROM SPACE}

T ropospheric ozone is the central character that drives the chemistry of the lower atmosphere. From an atmospheric chemist's point of view, if the global distribution of tropospheric ozone and the evolution of that distribution are understood, then many of the basic questions driving the science can be answered. The primary challenge is the fact that ozone is both a natural and a man-made component of the lower atmosphere (as opposed to the stratosphere, where ozone is produced only naturally). The two major sources of $\mathrm{O}_{3}$ are its transport from the huge stratospheric reservoir and its in situ photochemical production from the release of anthropogenic and biogenic precursors that are oxidized in the atmosphere to eventually become ozone. Most of these trace gases are initially oxidized by the $\mathrm{OH}$ radical and its abundance and distribution, in turn, are most dependent on the $\mathrm{O}_{3}$ present in the troposphere. Thus, if the distribution of $\mathrm{O}_{3}$ is well known, then we can get a good handle on the oxidizing capacity of the atmosphere and the global extent of air pollution, two of the "grand challenges" put forth in the integrated global observations strategy for atmospheric composition

FIG. SBI. Schematic diagram of simplified tropospheric photochemistry. Species in red can be measured using existing satellite instrumentation. $\mathrm{CO}, \mathrm{NO}$, and VOCs are emitted in the planetary boundary layer from both anthropogenic and biogenic sources. $\mathrm{NO}_{2}$ is rapidly converted in the troposphere from emitted NO and the two NO establish an equilibrium ratio between each other depending on a number of atmospheric variables, such as the intensity of sunlight and the amount of $\mathrm{O}_{3} . \mathrm{HCHO}$ is an intermediate product of VOC oxidation, and its measurement is a good indication of the amount of VOCs present. The amount of $\mathrm{O}_{3}$ produced is directly proportional to how much $\mathrm{NO}_{2}$ is present when sunlight is available (denoted by the "sun" symbol). Ozone can also be transported to the troposphere from the stratosphere where it is produced naturally by the photolysis of molecular oxygen $\left(\mathrm{O}_{2}\right)$ because of high-energy photons in the upper atmosphere $(\lambda<242 \mathrm{~nm})$ that are capable of breaking apart the $\mathrm{O}_{2}$ molecule. Lightning is also a natural source of $\mathrm{NO}_{x}$ in the free troposphere.
(Barrie et al. 2004). Global observations of trace gases using satellites have already provided the community with a unique set of observations that have yielded important insights by being able to measure $\mathrm{CO}, \mathrm{NO}_{2}, \mathrm{HCHO}$, and $\mathrm{O}_{3}$, itself.

Tropospheric $\mathrm{O}_{3}$ is formed when certain precursor trace gases are oxidized in the atmosphere by the $\mathrm{OH}$ radical. The two most important precursor trace gases are $\mathrm{CO}$ and a class of gases known as VOC species. However, the amount of $\mathrm{O}_{3}$ that forms is most critically dependent on the available concentration of $\mathrm{NO}_{x}$, which is primarily the sum of $\mathrm{NO}$ and $\mathrm{NO}_{2}$. Putting it into a chemical reaction formulation, there are two potential pathways:

VOC (or $\mathrm{CO})+\mathrm{OH}+$ sunlight $\left.\rightarrow \mathrm{H}_{2} \mathrm{O}+\mathrm{CO}_{2}(\text { no NO})_{x}\right)$

or

$\mathrm{VOC}($ or $\mathrm{CO})+\mathrm{OH}+$ sunlight $\rightarrow \mathrm{O}_{3}+\mathrm{H}_{2} \mathrm{O}+\mathrm{CO}_{2}$ (with $\mathrm{NO}_{x}$ ).

From satellites, we can measure $\mathrm{HCHO}$ (a surrogate for $\mathrm{VOC}$ ), $\mathrm{CO}, \mathrm{O}_{3}$, and $\mathrm{NO}_{2}$ (one of the two primary components of $\mathrm{NO}_{x}$ ).

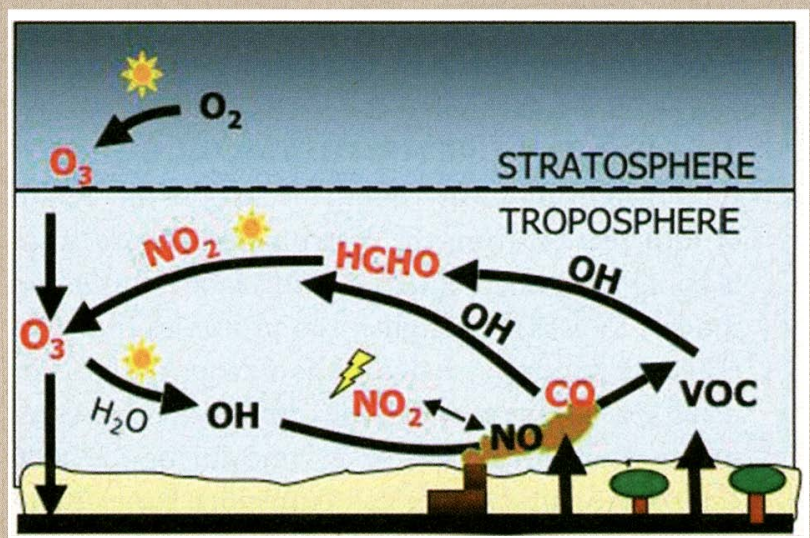


the south-central and eastern United States, but no significant $\mathrm{CO}$ enhancement off the California coast. The collocated tropospheric $\mathrm{O}_{3}$ and $\mathrm{CO}$ enhancements are due to photochemical ozone production and emissions associated with power generation facilities located east of the Mississippi and large urban centers along the Great Lakes and northeastern United States. The tropospheric $\mathrm{O}_{3}$ enhancements without significant $\mathrm{CO}$ enhancements are due to accumulation of stratospherically influenced air within the persistent subtropical high pressure system off the California coast.

With the capability to discriminate more than one layer in the troposphere, observations from TES have also provided new insight into how the ozone maximum found off the west coast of Africa (Fishman et al. 1990, 1996) evolved (see Fig. 4). Subsequent to its discovery using satellite data, in situ observations from ship cruise campaigns (Thompson et al. 2000) and model studies (Edwards et al. 2003; Martin et al. 2002) showed that the early-year tropospheric ozone distribution over the tropical Atlantic Ocean is characterized by two maxima-one in the lower troposphere north of the intertropical convergence zone (ITCZ) and one in the middle and upper troposphere south of the ITCZ. This feature could not be resolved from the original analysis using the remote-sensing capabilities available in the 1990s. In Jourdain et al. (2007), TES vertical ozone retrievals provided the first space-based observations that characterized this complex altitude-dependent interplay between chemistry and transport. In particular, an enhanced layer of $\mathrm{O}_{3}$ was observed by TES below $600 \mathrm{hPa}$ that was advected by Harmattan winds from burning over western and central Africa.

\section{THE RESEARCH-TO-APPLICATIONS PARADIGM FOR AIR QUALITY MEASURE- MENTS FROM SPACE: RECOMMENDA- TIONS FROM THE NRC DECADAL SURVEY.}

As shown from the preceding discussion, the wealth of information from the instruments aboard Aura is being used in conjunction with data assimilation models to provide insights into processes that take place on synoptic scales. This new paradigm for using spaceborne atmospheric composition measurements was tested in near-real time during the 2006 Intercontinental Chemical Transport Experiment (INTEX)-B and Texas Air Quality Study (TexAQS) field campaigns. Initially the foci of these multiagency integrated satellite-aircraft campaigns were distinct and different: the objective of INTEX-B was to investigate the transport and transformation of pollution from Asia to North America, whereas the TexAQS2006 campaign focused on the effects of distant and local sources on air quality in Texas. Collectively, however, these studies provided an exciting opportunity to investigate global and regional impacts of air quality using a variety of spaceborne sensors. The integration of these measurements with in situ data, models, and assimilation techniques has yielded rich gains in our understanding of air quality (see information online at www.espo.nasa.gov/intex-b/index. html; http://esrl.noaa.gov/csd/2006/). In addition, the National Research Council (2007) promotes this approach as a new paradigm for air quality prediction analogous to the pioneering efforts of the weather community during the second half of the twentieth century when hourly observations from geostationary platforms were looped through computer animation to provide unique insights into cloud formation and water vapor transport.

With respect to atmospheric composition, the first operational products have become a reality in recent years (Al-Saadi et al. 2005; see also information online at http://idea.ssec.wisc.edu/; http://airnow.gov/). This information is used to advise people to remain indoors if they are susceptible to respiratory stress when exposed to elevated levels of pollution. The use of future satellite technology to improve forecasts of detrimental aspects of air quality underlay the NRC's recommendation for the next atmospheric composition mission to be from geostationary orbit.

The atmospheric chemistry-composition community has traditionally not faced the challenge of using tropospheric trace species measurements in a forecast mode, and as the NRC report clearly indicates, the tools currently do not exist to use such information. The most obvious missing piece is the lack of sufficient temporal resolution. An example of this shortcoming is shown in Fig. 11, which summarizes model results and measurements obtained during an Aura validation campaign on 22 and 23 June 2005. The two OMI $\mathrm{NO}_{2}$ column measurements over Houston are depicted by the red circles on the plot and were made at 1900 UTC on each day; the distribution at the time of the measurement for the 2 days is shown in the center and right panels above the plots. The left-top panel shows the $\mathrm{NO}_{2}$ column distribution calculated with the Community Multiscale Air Quality (CMAQ) model (Byun and Ching 1999). On the hourly plot, there are two sets of calculated quantities: surface $\mathrm{NO}_{2}$ concentration (magenta) and integrated tropospheric $\mathrm{NO}_{2}$ (dark blue), the latter being measured by OMI. Because its distribution is dominated by local sources (see Fig. 5), the $\mathrm{NO}_{2}$ observed by the 
satellite is closely linked to its concentration at the surface. Furthermore, the diurnal behavior of these quantities is also closely linked. If an instrument with spectral resolution comparable to that of OMI were in geostationary orbit, hourly observations of the type indicated by the blue diamonds during daylight hours (yellow shading) would be possible. Thus, an instrument using today's measurement capability that "stares" at a region throughout the course of the day would capture the most significant part of the diurnal variability that is totally missed by the low-Earth-orbiting Aura platform, which finds $\mathrm{NO}_{2}$ values of 8 and $4 \times 10^{15}$ molecules $\mathrm{cm}^{-2}$, for 22 and 23 June, respectively.

To improve the ability to measure ozone in the lower atmosphere, and especially near the surface, important advances in instrument capability may also be needed (Edwards 2006). Recently, Worden et al. (2007) showed the potential of combining UV and IR spectral radiances from both TES and OMI in a unified retrieval algorithm with significantly improved sensitivity in the troposphere. This approach may lay the groundwork for a new class of instruments that incorporate wavelengths across the ultraviolet, visible, and infrared spectrums that could revolutionize our observational capability from space of $\mathrm{CO}$ and $\mathrm{O}_{3}$ within the planetary boundary layer, and usher in a new era of air quality forecasting and prediction. The use of the Geostationary Imaging Fourier Transform Spectrometer (Smith et al. 2005) for trace gas measurements, active remote sensing for trace gases such as ozone (Browell et al. 2004) from low-Earth orbit, or the placement of an instrument with the powerful spectral resolution of an instrument like IASI in geostationary orbit provide the promise of additional techniques that will advance measurement capability beyond the time frame addressed in the decadal survey.
Regardless of the instrumentation that eventually resides in geostationary orbit to provide continuous high-spatial-resolution measurements of tropospheric trace gases (and aerosols), a substantial challenge also awaits the general atmospheric chemistry/ composition community to develop the mathematical tools that use this information. This point is emphasized in the Integrated Global Atmospheric Chemistry Observations strategy (Barrie et al. 2004), which cited the multipronged necessity of a strong modeling component as part of an integrated approach that will provide insight into tropospheric chemical and transport processes. Additionally, the modeling component will serve as the foundation for the eventual development of a robust air quality forecasting capability. As part of Global Earth Observation System of Systems (GEOSS; online at www.epa.gov/geoss), the satellite system of measurements needs to be integrated with data from groundbased observational (atmospheric composition) sites 
to develop a seamless three-dimensional field that can be used for both research and operational purposes. As pointed out by the air quality/atmospheric chemistry satellite science community (Edwards 2006), the biggest piece missing in the grandiose scheme of GEOSS is the type of measurement capability that can be obtained only from a geostationary satellite. The NRC provides a roadmap that recommends such a mission in the 2013-16 time frame.

The basic technology specifically mentioned in the decadal survey already exists and has been successfully demonstrated from LEO platforms. From the traditional meteorological perspective, the use of satellite information made a quantum leap when sensors were placed upon geostationary platforms. There is no doubt that similar advancements will be realized when sensors devoted to atmospheric composition measurements are likewise put on a geostationary platform.

ACKNOWLEDGMENTS. The views, opinions, and findings contained in this report are those of the author(s) and should not be construed as an official National Oceanic and Atmospheric Administration or U.S. Government position, policy, or decision.

\section{REFERENCES}

Abbot, D. S., P. I. Palmer, R. V. Martin, K. V. Chance, D. J. Jacob, and A. Guenther, 2003: Seasonal and interannual variability of North American isoprene emissions as determined by formaldehyde column emissions from space. Geophys. Res. Lett., 30, 1886, doi:10.1029/2003GL017336.

Al-Saadi, J., and Coauthors, 2005: Improving national air quality forecasts with satellite aerosol observations. Bull. Amer. Meteor. Soc., 86, 1249-1261.

Barret, B., S. Turquety, D. Hurtmans, C. Clerbaux, J. Hadju-Lazaro, I. Bey, M. Auvray, and P.-F. Coheur, 2005: Global carbon monoxide vertical distributions from spaceborne high-resolution FTIR nadir measurements. Atmos. Chem. Phys., 5, 2901-2914.

Barrie, L. A., P. Borrell, and J. Langen, Eds., 2004: The changing atmosphere, an integrated global atmospheric chemistry observation (IGACO) theme for the IGOS partnership. Global Atmospheric Watch Rep. 159, World Meteorological TD 1235, 54 pp.

Beer, R., T. Glavich, and D. Rider, 2001: Tropospheric emission spectrometer for the Earth Observing System's Aura satellite. Appl. Opt., 40, 2356-2367.

Beirle, S., U. Platt, M. Wenig, and T. Wagner, 2003: Weekly cycle of $\mathrm{NO}_{2}$ by GOME measurements: A signature of anthropogenic sources. Amer. Chem. Phys., 3, 2225-2232.

Bell, M. L., A. McDermott, S. L. Zeger, J. M. Samet, and F. Dominici, 2004: Ozone and short-term mortality in 95 U.S. urban communities. J. Amer. Med. Assoc., 292, 2372-2378.

Bhartia, P. K., R. D. McPeters, C. L. Mateer, L. E. Flynn, and C. Wellemeyer, 1996: Algorithm for the estimation of vertical ozone profiles from the backscattered ultraviolet technique. J. Geophys. Res., 101, 18 793-18 806.

Boersma, K. F., H. J. Eskes, and E. J. Brinksma, 2004: Error analysis for tropospheric $\mathrm{NO}_{2}$ retrieval from space. J. Geophys. Res., 109, D043011, doi:10.1029/ 2003JD003962.

Browell, E. V., W. B. Grant, and S. Ismail, 2004: Environmental measurements: Laser detection of atmospheric trace gases. Encyclopedia of Modern Optics, R. D. Guenther, D. G. Steel, and L. Bayvel, Eds., Elsevier, 403-416.

Bucsela, E. J., E. A. Celarier, M. O. Wenig, J. F. Gleason, J. P. Veefkind, K. F. Boersma, and E. J. Brinksma, 2006: Algorithm for $\mathrm{NO}_{2}$ vertical column retrieval from the ozone monitoring instrument. IEEE Trans. Geosci. Remote Sens., 44, 1245-1258.

Burrows, J. P., 1999: Current and future passive remote sensing techniques used to determine atmospheric constituents. Approaches to Scaling of Trace Gas Fluxes in Ecosystems, A. F. Bouwman, Ed., Elsevier, 317-347.

Byun, D. W., J. K. S. Ching, Eds., 1999: Science algorithms for the EPA Models-3 Community Multiscale Air Quality (CMAQ) Modeling System. CMAQ Science Doc. EPA-600/R-99/30, 611 pp.

Chance, K. V., J. P. Burrows, and W. Schneider, 1991: Retrieval and molecule sensitivity studies for the Global Ozone Monitoring Experiment and the Scanning Imaging Absorption Spectrometer for Atmospheric Chartography. Proc. SPIE Remote Sens. Atmos. Chem., 1491, 151-165.

—, — D. Perner, and W. Schneider, 1997: Satellite measurements of atmospheric ozone profiles, including tropospheric ozone, from UV/visible measurements in the nadir geometry: A potential method to retrieve tropospheric ozone. J. Quant. Spectrosc. Radiative Transfer, 57, 467-476.

—, P. I. Palmer, R. J. D. Spurr, R. V. Martin, T. P. Kurosu, and D. J. Jacob, 2000: Satellite observations of formaldehyde over North America from GOME. Geophys. Res. Lett., 27, 3461-3464.

Crutzen, P. J., and J. Fishman, 1977: Average concentrations of $\mathrm{OH}$ in the Northern Hemisphere and the budgets of $\mathrm{CH}_{4}, \mathrm{CO}$, and $\mathrm{H}_{2}$. Geophys. Res. Lett., 4, 321-324. 
Dabberdt, W. F., and Coauthors, 2003: Meteorological research needs for improved air quality forecasting. Bull. Amer. Meteor. Soc., 84, 563-585.

Edwards, D. P., 2006: Air quality remote sensing from space. Eos, Trans. Amer. Geophys. Union, 87, 327.

—, and Coauthors, 2003: Tropospheric ozone over the tropical Atlantic: A satellite perspective. Geophys. Res., 108, 4237, doi:10.1029/2002JD002927.

— , and Coauthors, 2004: Observations of carbon monoxide and aerosol from the Terra satellite: Northern Hemisphere variability. J. Geophys. Res., 109, D24202, doi:10.1029/2004JD0047272.

—, A. Pétron, P. C. Novelli, L. K. Emmons, J. C. Gille, and J. R. Drummond, 2006: Southern Hemisphere carbon monoxide interannual variability observed by Terra/Measurement of Pollution in the Troposphere (MOPITT). J. Geophys. Res., 111, D16303, doi:10.1029/2006JD007079.

Fishman, J., and W. Seiler, 1983: Correlative nature of ozone and carbon monoxide in the troposphere: Implications for the tropospheric ozone budget. $J$. Geophys. Res., 88, 3662-3670.

— ozone and stratospheric ozone in the tropics: Implications for the distribution of tropospheric ozone. J. Geophys. Res., 92, 6627-6634.

_, P. Minnis, and H. G. Reichle Jr., 1986: Use of satellite data to study trace gas emissions in the tropics. J. Geophys. Res., 91, 14 451-14 465.

—, C. E. Watson, J. C. Larsen, and J. A. Logan, 1990: Distribution of tropospheric ozone determined from satellite data. J. Geophys. Res., 95, 3599-3617.

—, J. M. Hoell Jr., R. D. Bendura, V. W. J. H. Kirchhoff, and R. J. McNeal, 1996: The NASA GTE TRACE-A experiment (September-October, 1992). J. Geophys. Res., 101, 23 865-23 879.

—, A. E. Wozniak, and J. K. Creilson, 2003: Global distribution of tropospheric ozone from satellite measurements using the empirically corrected tropospheric ozone residual technique: Identification of the regional aspects of air pollution. Atmos. Chem. Phys., 3, 893-907.

—, J. K. Creilson, A. E. Wozniak, and P. J. Crutzen, 2005: Interannual variability of stratospheric and tropospheric ozone determined from satellite measurements. J. Geophys. Res., 110, D20306, doi:10.1029/2005JD005868.

Fu, T.-M., and Coauthors, 2007: Space-based formaldehyde measurements as constraints on volatile organic compound emissions in East and South Asia, and implications for ozone. J. Geophys. Res., 112, D06312, doi:10.1029/2006JD007853.
Hadji-Lazaro, J., C. Clerbaux, and S. Thiria, 1999: An inversion algorithm using neural networks to retrieve atmospheric CO total columns from highresolution nadir radiances. J. Geophys. Res., 104, 23 841-23 854.

Hanel, R., and B. J. Conrath, 1969: Interferometer experiment on Nimbus 3: Preliminary results. Science, $165,1258$.

Hoogen, R., V. V. Rozanov, and J. P. Burrows, 1999: Ozone profiles from GOME satellite data: Algorithm description and first validation. J. Geophys. Res., 104, 8263-8280.

Jaeglé, L., L. Steinberger, R. V. Martin, and K. Chance, 2005: Global partitioning of $\mathrm{NO}_{\mathrm{x}}$ sources using satellite observations: Relative roles of fossil fuel combustion, biomass burning and soil emissions. Faraday Discuss., 130, 407-423.

Jiang, Y. B., and Y. L. Yung, 1996: Concentrations of tropospheric ozone from 1979 to 1992 over tropical Pacific South America from TOMS data. Science, 272, 714-716.

Jourdain, L., and Coauthors, 2007: Tropospheric vertical distribution of tropical Atlantic ozone observed by TES during the northern African biomass burning season. Geophys. Res. Lett., 34, L04810, doi:10.1029/ 2006 GL028284.

Kaye, J. A., and J. Fishman, 2003: Stratospheric ozone observations. Handbook of Climate, Weather, and Water: Chemistry, Impacts and Applications. T. D. Potter and B. Colman, Eds., Wiley, 385-404.

Kurosu, T. P., K. Chance, and R. Volkamer, 2005: Global measurements of $\mathrm{OC} 1 \mathrm{O}, \mathrm{BrO}, \mathrm{HCHO}$, and $\mathrm{CHO}$ $\mathrm{CHO}$ from the ozone monitoring instruments on EOS Aura. AGU Fall Meeting, San Francisco, CA, Amer. Geophys. Union, Abstract A54B-01.

Lamarque, J.-.F., and Coauthors, 2003: Identification of CO plumes from MOPITT data: Application to the August 2000 Idaho-Montana forest fires. Geophys. Res. Lett., 30, 1688, doi:10.1029/ 2003 GL017503.

Leue, C., M. Wenig, T. Wagner, O. Klimm, U. Platt, and B. Jahne, 2001: Quantitative analysis of $\mathrm{NO}_{\mathrm{x}}$ emissions from GOME satellite image sequences. J. Geophys. Res., 106, 5493-5505.

Levy, H., II, 1971: Normal atmosphere: Large radical and formaldehyde concentrations predicted. Science, 173, 141-143.

Liu, X., K. Chance, C. E. Sioris, R. J. D. Spurr, T. P. Kurosu, R. V. Martin, and M. J. Newchurch, 2005: Ozone profile and tropospheric ozone retrievals from Global Ozone Monitoring Experiment: Algorithm description and validation. J. Geophys. Res., 110, D20307, doi:10.1029/2005JD006240. 
— , and Coauthors, 2006: First directly retrieved global distribution of tropospheric column ozone from GOME: Comparison with the GEOS-CHEM model. J. Geophys. Res., 111, D02308, doi:10.1029/ 2005JD006564.

Martin, R. V., and Coauthors, 2002: An improved retrieval of tropospheric nitrogen dioxide from GOME. J. Geophys. Res., 107, 4437, doi:10.1029/ 2001JD001027.

- D. J. Jacob, K. Chance, T. P. Kurosu, P. I. Palmer, and M. J. Evans, 2003: Global inventory of nitrogen oxide emissions constrained by space-based observations of $\mathrm{NO}_{2}$ columns. J. Geophys. Res., 108, 4537, doi:10.1029/2003JD003453.

— - and Coauthors, 2006: Evaluation of space-based constraints on global nitrogen oxide emissions with regional aircraft measurements over and downwind of eastern North America. J. Geophys. Res., 111, D15308, doi:10.1029/2005JD006680.

Mauzerall, D. L., and X. Wang, 2001: Protecting agricultural crops from the effects of tropospheric ozone exposure: Reconciling science and standard setting in the United States, Europe, and Asia. Annu. Rev. Energy Environ., 26, 237-268.

McConnell, J. C., M. B. McElroy, and S. C. Wofsy, 1971: Natural sources of atmospheric CO. Nature, 233, 187-188.

McHenry, J. N., and W. F. Dabberdt, 2005: Air quality and meteorological monitoring strategies to advance air quality modeling and its application to operational air quality forecasting. EPA Rep. EPA/600/ R-05/154, 78 pp.

McMillan, W. W., and Coauthors, 2005: Daily global maps of carbon monoxide: First views from NASA's Atmospheric Infrared Sounder. Geophys. Res. Lett., 32, L11801, doi:10.1029/2004GL021821.

Molina, M. J., and F. S. Rowland, 1974: Stratospheric sink for chlorofluoromethanes: chlorine atom catalyzed destruction of ozone, Nature, 249, 3100-3104.

Morgan, P. B., E. A. Ainsworth, and S. P. Long, 2003: How does elevated ozone impact soybean? A metaanalysis of photosynthesis, growth and yield. Plant, Cell Environ., 26, 1317-1328.

Morris, G. A., and Coauthors, 2006: Alaskan and Canadian forest fires exacerbate ozone pollution over Houston, Texas, on 19 and 20 July 2004. J. Geophys. Res., 111, D24S03, doi:10.1029/ 2006JD007090.

Munro, R., R. Siddans, W. J. Reburn, and B. Kerridge, 1998: Direct measurement of tropospheric ozone from space. Nature, 392, 168-171.

National Academy of Science, 1977: Carbon Monoxide. National Academy Press, 239 pp.
National Research Council, 2007: Earth Science and Applications from Space: National Imperatives for the Next Decade and Beyond. National Academy Press, 428 pp.

—, 2008: Earth Observations from Space: The First 50 Years of Scientific Achievements. National Academy Press, 129 pp.

Newchurch, M. J., X. Liu, and J. H. Kim, 2001: Lowertropospheric ozone (LTO) derived from TOMS near mountainous regions. J. Geophys. Res., 106, 20 403-20 412.

Pfister, G., and Coauthors, 2005: Quantifying CO emissions from the 2004 Alaskan wildfires using MOPITT CO data. Geophys. Res. Lett., 32, L11809, doi:10.1029/2005GL022995.

Pierce, R. B., and Coauthors, 2003: Regional Air Quality Modeling System (RAQMS) predictions of the tropospheric ozone budget over east Asia. J. Geophys. Res., 108, 8825, doi:10.1029/2002JD003176.

- and Coauthors, 2007: Chemical data assimilation estimates of continental U.S. ozone and nitrogen budgets during the Intercontinental Chemical Transport Experiment-North America. J. Geophys. Res., 112, D12S21, doi:10.1029/ 2006JD007722.

Pope, C. A., 2000: Epidemiology of fine particulate air pollution and human health: Biologic mechanisms and who's at risk? Environ. Health Perspect., 108, 713-723.

Reichle, H. G., Jr., and Coauthors, 1986: Middle and upper tropospheric carbon monoxide mixing ratios as measured by a satellite borne remote sensor during November 1981. J. Geophys. Res., 91, $10865-10887$.

_ - and Coauthors, 1999: Space shuttle based global CO measurements during April and October 1994, MAPS instrument, data reduction, and data validation. J. Geophys. Res., 104, 21 443-21 454.

Richter, A., and J. P. Burrows, 2002: Tropospheric $\mathrm{NO}_{2}$ from GOME measurements. Adv. Space Res., 29, 1673-1683.

— - — - H. Nü $\beta$, C. Granier, and U. Niemeier, 2005: Significant increase in tropospheric nitrogen dioxide over China observed from space. Nature, 437, 129-132.

Seiler, W., 1974: The cycle of atmospheric CO. Tellus, 26, 116-135.

Shim, C., Y. Wang, Y. Choi, P. I. Palmer, D. S. Abbot, and $\mathrm{K}$. Chance, 2005: Constraining global isoprene emissions with Global Ozone Monitoring Experiment (GOME) formaldehyde column measurements. J. Geophys. Res., 110, D24301, doi:10.1029/ 2004JD005629. 
Smith, W. L. Sr., H. E. Revercomb, D. K. Zhou, and H. L. Huang, 2005: Hyperspectral sounding-A revolutionary advance in atmospheric remote sensing. Proc. SPIE, 5655, 1-11.

Thomas, W., E. Hegels, S. Slijkhuis, R. Spurr, and K. Chance, 1998: Detection of biomass burning combustion products in South-east Asia from backscatter data taken by the GOME spectrometer. Geophys. Res. Lett., 25, 1317-1320.

Thompson, A. M., 1992: The oxidizing capacity of the Earth's atmosphere: Probable past and future changes. Science, 256, 1157-1165.

—, and R. D. Hudson, 1999: Tropical tropospheric ozone (TTO) maps from Nimbus and Earth-Probe TOMS by the modified residual method: Evaluation with sondes, ENSO signals and trends from Atlantic regional time series. J. Geophys. Res., 104, 26 961-26975.

— , and Coauthors, 2000: A tropical atlantic ozone paradox: Shipboard and satellite views of a tropospheric ozone maximum and wave-one in January-February 1999. Geophys. Res. Lett., 27, 3317-3320.

—, and Coauthors, 2007: Intercontinental Chemical Transport Experiment Ozonesonde Network Study (IONS) 2004: 1. Summertime upper troposphere/ lower stratosphere ozone over northeastern North America. J. Geophys. Res., 112, D12S12, doi:10.1029/ 2006JD007441.

Turquety, S., J. Hadji-Lazaro, C. Clerbaux, D. A. Hauglustaine, S. A. Clough, V. Cassé, P. Schlüssel, and G. Mégie, 2004: Operational trace gas retrieval algorithm for the Infrared Atmospheric Sounding Interferometer. J. Geophys. Res., 109, D21301, doi:10.1029/2004JD004821.

Volkamer, R., L. T. Molina, M. J. Molina, T. Shirley, and W. H. Brune, 2005: DOAS measurement of glyoxal as an indicator for fast VOC chemistry in urban air. Geophys. Res. Lett., 32, L08806, doi:10.1029/ 2005 GL022616.
Wang, P.-H., and Coauthors, 2006: Ozone variability in the midlatitude upper troposphere and lower stratosphere diagnosed from a monthly SAGE II climatology relative to the tropopause. J. Geophys. Res., 111, D21304, doi:10.1029/2005JD006108.

Warner, J., M. McCourt Comer, D. D. Barnet, W. W. McMillan, W. Wolf, E. Maddy, and G. Sachse, 2007: A comparison of satellite tropospheric carbon monoxide measurements from AIRS and MOPITT during INTEX-A. J. Geophys. Res., 112, D12S17, doi:10.1029/2006JD007925.

Wittrock, F., and Coauthors, 2006: Simultaneous global observations of glyoxal and formaldehyde from space. Geophys. Res. Lett., 33, L16804, doi:10.1029/ 2006 GL026310.

Worden, J., X. Liu, K. Bowman, K. Chance, R. Beer, A. Eldering, M. Gunson, and H. Worden, 2007; Improved tropospheric ozone profile retrievals using OMI and TES radiances. Geophys. Res. Lett., 34, L01809, doi:10.1029/2006GL027806.

Yurganov, L. N., and Coauthors, 2005: Increased Northern Hemispheric carbon monoxide burden in the troposphere in 2002 and 2003 detected from the ground and from space. Atmos. Chem. Phys., 5, 563-573.

Ziemke, J. R., S. Chandra, and P. K. Bhartia, 1998: Two new methods for deriving tropospheric column ozone from TOMS measurements: Assimilated UARS MLS/HALOE and convective-cloud differential techniques. J. Geophys. Res., 103, 22 115-22 127.

,$- \ldots$, and —_, 2001: "Cloud slicing": A new technique to derive upper tropospheric ozone from satellite measurements. J. Geophys. Res., 106, 9853-9867.

,-- , and - , 2005: A 25-year data record of atmospheric ozone from Total Ozone Mapping Spectrometer (TOMS) cloud slicing: Implications for ozone trends in the stratosphere and troposphere. J. Geophys. Res., 110, D15105, doi:10.1029/ 2004JD005687.

\section{TELL YOUR COLLEAGUES!}

Our new simplified application form makes joining the AMS easier than ever!

Applications are now being accepted online at www.ametsoc.org. 


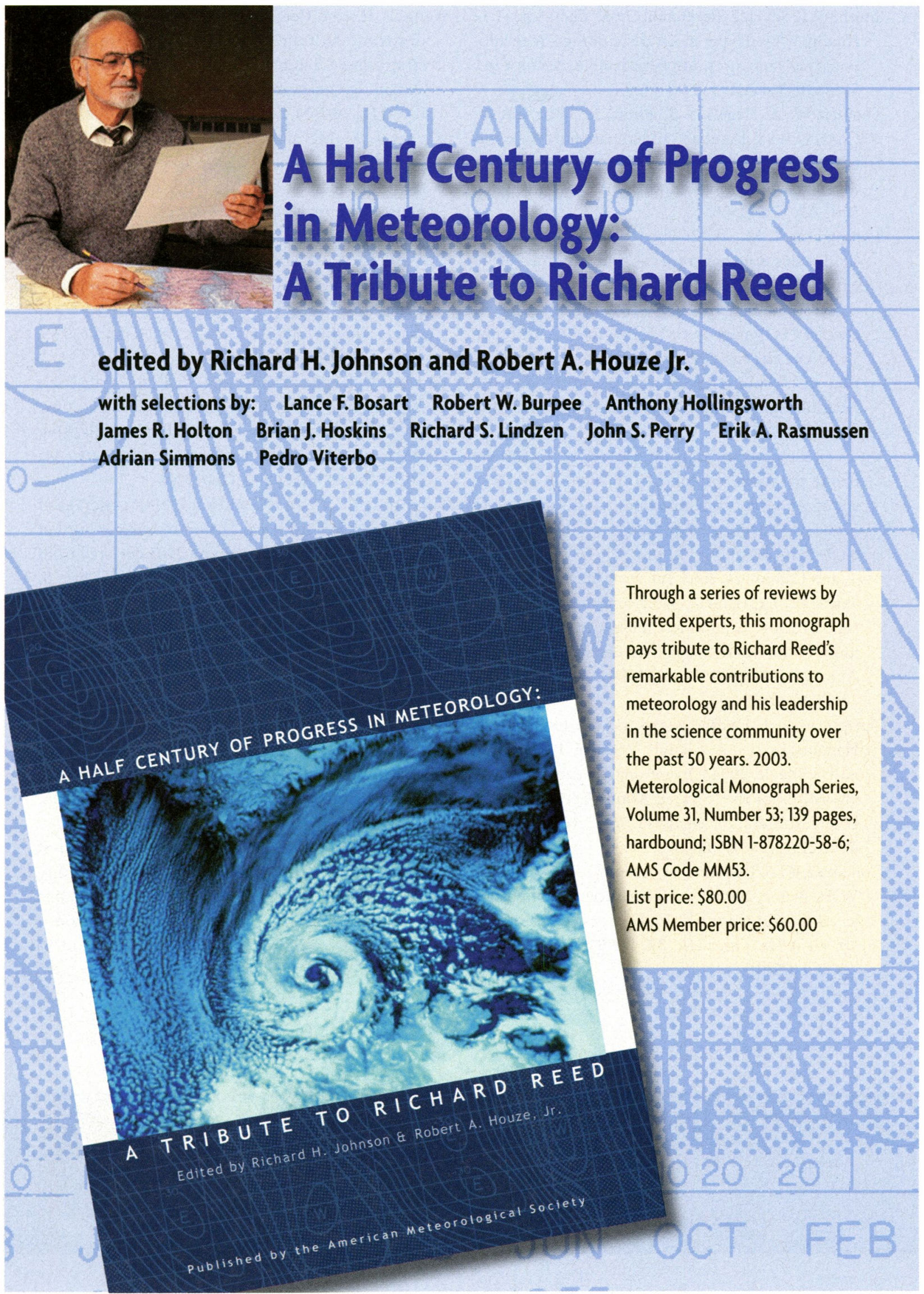

